\title{
A Time-Extended (24 h) Baited Remote Underwater Video (BRUV) for Monitoring Pelagic and Nocturnal Marine Species
}

\author{
Agusti Torres ${ }^{1}$, Ana-Maria Abril ${ }^{1,2}$ and Eric E. G. Clua ${ }^{1,3,4, *(1)}$ \\ 1 Shark-Med Association, Calle Joan Bonet, 25, Planta Baja, 07004 Palma de Mallorca, Illes Balears, Spain; \\ agustitorresdomenge@gmail.com (A.T.); anamariabril@gmail.com (A.-M.A.) \\ 2 Department de Biologia. Cra. de Valldemossa, Universitat de les Illes Balears, km 7.5., \\ 07004 Palma de Mallorca, Illes Balears, Spain \\ 3 PSL (Paris Science et Lettres) Université Paris: EPHE-UPVD-CNRS, USR 3278 CRIOBE BP 1013, \\ 98729 Papetoai, Moorea, French Polynesia \\ 4 Laboratoire d'Excellence 'CORAIL', 58 avenue Paul Alduy, F-66360 Perpignan, France \\ * Correspondence: eric.clua@gmail.com
}

Received: 17 February 2020; Accepted: 14 March 2020; Published: 18 March 2020

\begin{abstract}
Baited remote underwater video systems (BRUVs) are efficient devices for remotely characterising the assemblage and relative density of fishes and other marine organisms. However, technological constraints (e.g., battery life and limited storage memory) typically limit deployment times to $<2 \mathrm{~h}$ making it very difficult to capture the presence of marine species, including rare and elusive ones. We developed an extended duration ( $24 \mathrm{~h}$ ) BRUV to enable fisheries-independent surveying of a pelagic shark population in the western Mediterranean. Video data revealed seven visits (three nocturnal, four diurnal) by blue sharks (Prionace glauca) over a period of $1355 \mathrm{~h}$. In the future, this cost-effective device could be fitted with a wireless video transmitter to provide real-time observations of marine animals for scientific or ecotourism purposes.
\end{abstract}

Keywords: marine fauna observation; shark densities assessment; fisheries-independent assessment; underwater visual census; blue shark Prionace glauca

\section{Introduction}

Thanks to advances in digital camera and battery technologies, the use of baited remote underwater video systems (BRUVs) has increased since initial deployments in the 1990s [1,2]. Despite relatively high device cost and labor-intensive video data analysis [3], BRUVs have been widely used in studies characterising species diversity and abundance of fishes (see review by [4]). The diversity of BRUV studies includes characterisation of mesophotic (30-150 m depth) reef fish communities [5], monitoring of the fish fauna associated with seagrass habitats [6], assessment of behavioural responses to playback noise [7], and the attractiveness of animal vs plant-based baits to reef fishes [8]. The strong attractiveness of bait to sharks [9], has also made BRUVs efficient tools for assessing shark populations. For example, a recent worldwide project (see www.globalfinprint.com) [10] deployed thousands of BRUVs across the globe, and allowed drivers-such as heavy fishing pressure or illegal fishing-for diversities and densities of coastal sharks, to be identified [11,12].

Given the importance of sharks as apex and mesopredators for the balance and productivity of marine ecosystems, their decline in some regions in recent decades is of particular concern $[13,14]$. In the Mediterranean, this trend has led to declines in large species and to population collapses of $96-99 \%$, with overfishing being the most prevalent threat [15]. Moreover, it has become particularly difficult to observe and detect large sharks in the Mediterranean. BRUVs could potentially provide an effective 
fisheries-independent method of monitoring diminished shark populations, but only if recording times can be increased significantly beyond current norms in order to effectively sample low shark densities. For example, the duration of video sampling in the Finprint project [10] is 60-90 min which may be too short to document sharks in locations where their populations have been heavily diminished by fishing. The short duration of video sampling is due primarily to the power and memory-intensive nature of video data. However, recent technological advances have enabled us to build and deploy a cost-effective BRUV system capable of recording high quality video for up to $24 \mathrm{~h}$. Here we describe the use of this system to characterise shark abundance and diversity in the heavily fished waters of the Balearic archipelago in the western Mediterranean.

\section{Material and Methods}

\subsection{Study Site and Sampling Effort}

The Balearic archipelago is located in the western Mediterranean Sea about $200 \mathrm{~km}$ from the east coast of the Iberian Peninsula. The main island of Mallorca is surrounded by four other smaller islands, including the island of Menorca in the northeast. Seawater temperatures vary between $14-15{ }^{\circ} \mathrm{C}$ in winter and $24-25^{\circ} \mathrm{C}$ in summer. About twenty species of sharks have been documented in waters surrounding the archipelago, including the great white shark Carcharodon carcharias, which was commonly captured until the late 1970s [16], the copper shark Carcharhinus brachyurus [17], as well as the blacktip shark C. limbatus, and the sandbar shark C. plumbeus [18]. Sampling effort was concentrated around the island of Mallorca, with 12 BRUV deployments taking place between July 2017 and November 2019, during both winter $(n=6)$ and summer $(n=5)$, and a single deployment around the island of Menorca in summer (Table 1). Each deployment lasted from 3 to 10 days (determined by weather conditions) with an average duration of $112 \mathrm{~h}$ and $52 \mathrm{mn}$. The BRUV (see next paragraph) was anchored in epi-pelagic waters at an average distance from the coast of $8.15 \mathrm{~km}(+/-5.5 \mathrm{~km})$ and an average depth of $72 \mathrm{~m}(+/-27 \mathrm{~m})$ (Table 1$)$, with the bait positioned just below the surface.

Table 1. Details of baited remote underwater video systems (BRUV) sampling effort around Mallorca and Menorca islands.

\begin{tabular}{|c|c|c|c|c|c|c|c|c|c|}
\hline & Location & Coordinates & $\begin{array}{l}\text { Depth } \\
\text { (m) }\end{array}$ & $\begin{array}{c}\text { Average } \\
\text { Temp. }\left({ }^{\circ} \mathrm{C}\right)\end{array}$ & $\begin{array}{c}\text { Dist. To } \\
\text { Coast (Nm) }\end{array}$ & $\begin{array}{l}\text { Starting } \\
\text { Date }\end{array}$ & $\begin{array}{l}\text { Ending } \\
\text { Date }\end{array}$ & $\begin{array}{l}\text { Day } \\
\text { Hours }\end{array}$ & $\begin{array}{l}\text { Night } \\
\text { Hours }\end{array}$ \\
\hline \multirow{11}{*}{ Mallorca } & $\begin{array}{c}\text { Canal } \\
\text { Menorca }\end{array}$ & $\begin{array}{l}\text { N } 39^{\circ} 42^{\prime} 407 / \\
\text { E } 03^{\circ} 45^{\prime} 014\end{array}$ & 90 & 25 & 24.1 & 09/07/2017 & $11 / 07 / 2017$ & $36: 38: 00$ & $18: 22: 00$ \\
\hline & $\begin{array}{c}\text { Cap } \\
\text { Vermeil }\end{array}$ & $\begin{array}{c}\text { N 39 } 39^{\prime} 244 / \\
\text { E } 03^{\circ} 29^{\prime} 946\end{array}$ & 50 & 15 & 3.7 & 02/01/2018 & 05/01/2018 & $35: 18: 00$ & 43:42:00 \\
\hline & $\begin{array}{l}\text { Bahía de } \\
\text { Palma }\end{array}$ & $\begin{array}{c}\mathrm{N} 39^{\circ} 29^{\prime} 37.6^{\prime \prime} / \\
\mathrm{E} 02^{\circ} 41^{\prime} 54\end{array}$ & 30 & 15 & 0.6 & $23 / 01 / 2018$ & $25 / 01 / 2018$ & $26: 48: 00$ & 28:12:00 \\
\hline & $\begin{array}{l}\text { Bahía de } \\
\text { Pollença }\end{array}$ & $\begin{array}{c}\mathrm{N} 39^{\circ} 56^{\prime} 26.2^{\prime \prime} \mid \\
\mathrm{E} 03^{\circ} 11^{\prime} 49\end{array}$ & 40 & 14 & 3.7 & $12 / 03 / 2018$ & $17 / 03 / 2018$ & $65: 55: 00$ & 61:05:00 \\
\hline & \multirow{2}{*}{$\begin{array}{l}\text { Puerto de } \\
\text { Sóller }\end{array}$} & $\begin{array}{l}\text { N } 39^{\circ} 51^{\prime} 230 / \\
\text { E } 02^{\circ} 38^{\prime} 838\end{array}$ & 80 & 23 & 4.1 & $21 / 06 / 2018$ & $26 / 06 / 2018$ & $81: 55: 00$ & 45:05:00 \\
\hline & & $\begin{array}{l}\text { N } 39^{\circ} 51^{\prime} 230 / \\
\text { E } 02^{\circ} 38^{\prime} 838\end{array}$ & 80 & 26 & 7.4 & $17 / 07 / 2018$ & 19/07/2018 & $36: 19: 00$ & $18: 40: 00$ \\
\hline & $\begin{array}{c}\text { Cabo } \\
\text { Formentor }\end{array}$ & $\begin{array}{l}\text { N } 39^{\circ} 57,940 / \\
\text { E } 03^{\circ} 14,011\end{array}$ & 66 & 16 & 2.0 & $24 / 12 / 2018$ & $29 / 12 / 2018$ & 53:50:00 & 73:10:00 \\
\hline & $\begin{array}{l}\text { Puerto de } \\
\text { Sóller }\end{array}$ & $\begin{array}{l}\text { N } 39^{\circ} 49.794 / \\
\text { E } 02^{\circ} 39^{\prime} 921\end{array}$ & 65 & 14 & 7.4 & $12 / 02 / 2019$ & $18 / 02 / 2019$ & $52: 36: 00$ & $86: 24: 00$ \\
\hline & $\begin{array}{l}\text { Porto } \\
\text { Colom }\end{array}$ & $\begin{array}{l}\text { N } 39^{\circ} 23,110 / \\
\text { E } 03^{\circ} 17,311\end{array}$ & 55 & 14 & 3.0 & $10 / 03 / 2019$ & $14 / 03 / 2019$ & 43:09:00 & $49: 16: 00$ \\
\hline & \multirow{2}{*}{$\begin{array}{l}\text { Font de sa } \\
\quad \text { Cala }\end{array}$} & $\begin{array}{l}\text { N } 39^{\circ} 38,666 / \\
\text { E } 03^{\circ} 37,982\end{array}$ & 90 & 26 & 15.4 & 03/07/2019 & 13/07/2019 & 147:10:00 & $90: 50: 00$ \\
\hline & & $\begin{array}{c}\mathrm{N} 39^{\circ} 39.428^{\prime} / \\
\text { E } 03^{\circ} 38,328\end{array}$ & 90 & 22 & 15.4 & $27 / 10 / 2019$ & 02/11/2019 & $62: 10: 00$ & 79:48:00 \\
\hline \multirow[t]{2}{*}{ Menorca } & $\begin{array}{c}\text { Sa } \\
\text { Mezquida }\end{array}$ & $\begin{array}{l}\text { N } 39^{\circ} 56,023 / \\
\text { E } 04^{\circ} 22,260\end{array}$ & 130 & 27 & 7.4 & $15 / 08 / 2019$ & 20/08/2019 & $66: 55: 00$ & 51:15:00 \\
\hline & & & & & & & Total & 708:43:00 & 645:49:00 \\
\hline
\end{tabular}




\subsection{Method for Shark Attraction and Video Recording}

The long-endurance BRUV prototype consisted of a modified surfboard equipped with an anchoring system, underwater video camera, bait drum, solar charging system with battery, and a mast with a signal flag, radar reflector and white light (Figure 1). Baits used to attract sharks included fish scraps, cephalopods, and/or cetacean flesh and oil. The continuous video system consisted of a Hero3 GoPro camera (including a $256 \mathrm{~Gb}$ SD memory card that can store up to $27 \mathrm{~h}$ of continuous HD images) in a waterproof housing and an underwater white light source that switches on only at night. The system was powered by a 12 volt battery located inside a box on the board. A voltage regulator controlled the power supply to the camera and light, and also protected the battery against deep depletion. A $20 \mathrm{~W}$ solar panel mounted on the battery box charged a battery with enough capacity to power the underwater light for the duration of the night. The mast that supported the camera and the light was fixed under the board thanks to a removable mechanism that facilitates access to the camera for the exchange of memory cards. For each session, days and nights were recorded continuously, and the bait and camera memory card were renewed every $24 \mathrm{~h}$. Depending on whether the equipment was new or refurbished, the total cost of the device varied between 800 and 1500 US\$ (see Appendix A).

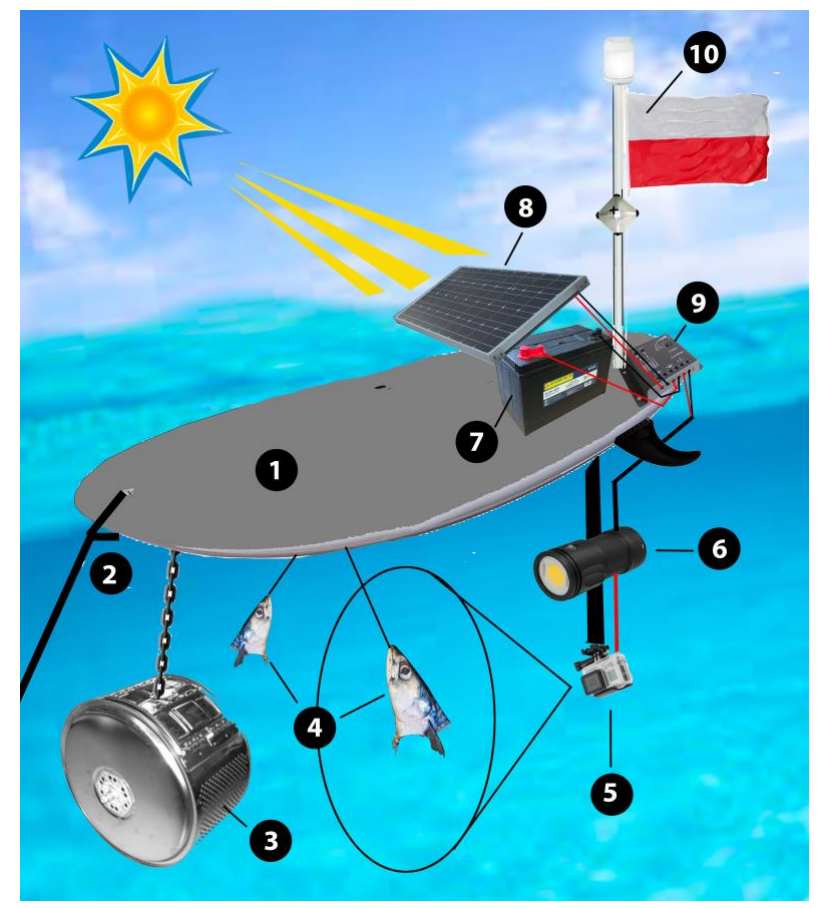

Figure 1. The BRUV includes the following components: (1) a surf board, (2) with an anchoring system, (3) (at a depth of $1 \mathrm{~m}$ ) a drum with holes that houses the bait (inaccessible for the predators) displaying the long-lasting olfactive stimulus, (4) additional accessible bait (here fish heads) attached (hookless) to monofilament strings including a swivel, an underwater stick that supports a (5) GoPro in a waterproof housing and an (6) underwater white light (in a waterproof housing), which are both powered by a (7) battery that is charged by a (8) solar panel and its (9) controller. The security of the device (to avoid any accidental collision by ships) is insured through a mast including a banner, a radar reflector and a white light for night positioning. The battery and the controller (voltage regulator) are housed in a box (not illustrated) that supports the solar panel. Accessible bait (4) must be positioned in order to allow the camera (5) to record any fish attempting to feed on it.

\section{Results}

A total of $1355 \mathrm{~h}$ of video was recorded during the 12 BRUV deployments with $52 \%$ and $48 \%$ of footage occurring during the day and night, respectively. Seven blue sharks Prionace glauca were recorded with an average duration of $3: 30 \mathrm{~h}(+/-230 \mathrm{~min}$ ) (from a minimum of $16 \mathrm{~min}$ up to $11 \mathrm{~h}$ ) 
between their first and last appearance. The sex of the animals was assessed based on the presence of claspers (for males) and the size of the animals was visually assessed by using the bait drum as a reference as each of the animals passed at least once at a short distance from the drum. Sharks observed included a female in "Canal de Menorca" (S\#1, July 2017), a female (S\#3) as well as three males (S\#2, S\#4 and S\#5, June 2018) and a female (S\#6, February 2019) in "Puerto de Soller", and a female (S\#7, July 2019) in "Font de Sa Cala" that were discriminated based on their gender, estimated size and special markings (Table 2). Among the seven sharks, three (43\%) of them were observed primarily $(>80 \%)$ at night (Figure 2 ). There was no significant difference in the number of sharks detected over short periods of deployment versus longer periods, as four sharks were sighted during a 7 day session (in June), while only one was sighted during two 3 day sessions (both in July) and one (in July) during a 10 day session. However, the season had a significant effect as only one shark among seven was detected during a winter session in February. The resolution of the footage was good enough to accurately identify individuals from their unique markings and detect hooks around the mouth of the animals (Figure 3).

Table 2. Description of the sharks with discriminating parameters.

\begin{tabular}{|c|c|c|c|c|}
\hline Shark ID & Session & Gender & Length Estimate & Special Markings \\
\hline$\# 1$ & Canal Menorca & $\mathrm{F}$ & $2 \mathrm{~m}$ & $\begin{array}{l}\text { No residual hook. } \\
\text { No specific marking. }\end{array}$ \\
\hline$\# 2$ & \multirow{4}{*}{ Puerto Soler 1} & M & $1.5 \mathrm{~m}$ & $\begin{array}{l}\text { Residual hook (right side) with a } \\
\text { nylon leader that exceeded the shark } \\
\text { length by }<2 \mathrm{~m} \text {. }\end{array}$ \\
\hline$\# 3$ & & $\mathrm{~F}$ & $1.2 \mathrm{~m}$ & $\begin{array}{l}\text { Residual hook (right side) with a } \\
\text { nylon leader that exceeded the shark } \\
\text { length by }>2 \mathrm{~m} \text {. }\end{array}$ \\
\hline$\# 4$ & & M & $1.5 \mathrm{~m}$ & $\begin{array}{l}\text { No residual hook (compared to } S \# 2 \text { ). } \\
\text { Sub-terminal notch on the tale less } \\
\text { pro-eminent than S\#2. }\end{array}$ \\
\hline$\# 5$ & & M & $2 \mathrm{~m}$ & $\begin{array}{l}\text { Different gender from other animals } \\
\text { of similar size (S\#1 and S\#7). }\end{array}$ \\
\hline \#6 & Puerto Soler 2 & $\mathrm{~F}$ & $1.6 \mathrm{~m}$ & $\begin{array}{l}\text { Different gender from other animals } \\
\text { of similar size (S\#2 and } S \# 4) \text {. }\end{array}$ \\
\hline$\# 7$ & Font de Sa Cala & $\mathrm{F}$ & $2 \mathrm{~m}$ & $\begin{array}{c}\text { Residual hook (right side) with heavy } \\
\text { algal fouling and without } \\
\text { nylon leader. }\end{array}$ \\
\hline
\end{tabular}

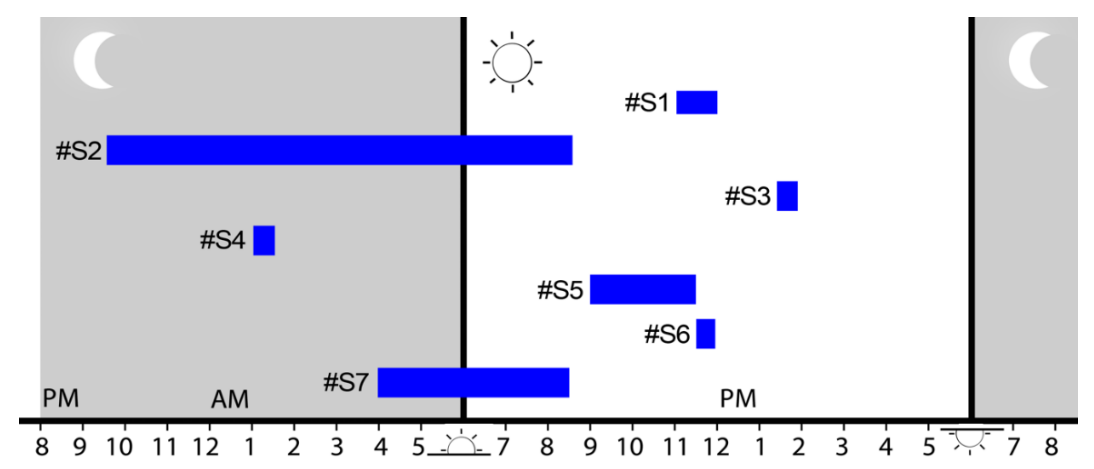

Figure 2. Occurrences of the seven blue sharks (numbered from \#S1 to \#S7) during the experiments showing four animals that appeared only during the day between 9 AM and 2 PM, and three animals that appeared mostly at night between 10 PM and 9 AM (appearance timing in contrasted blue colour). 


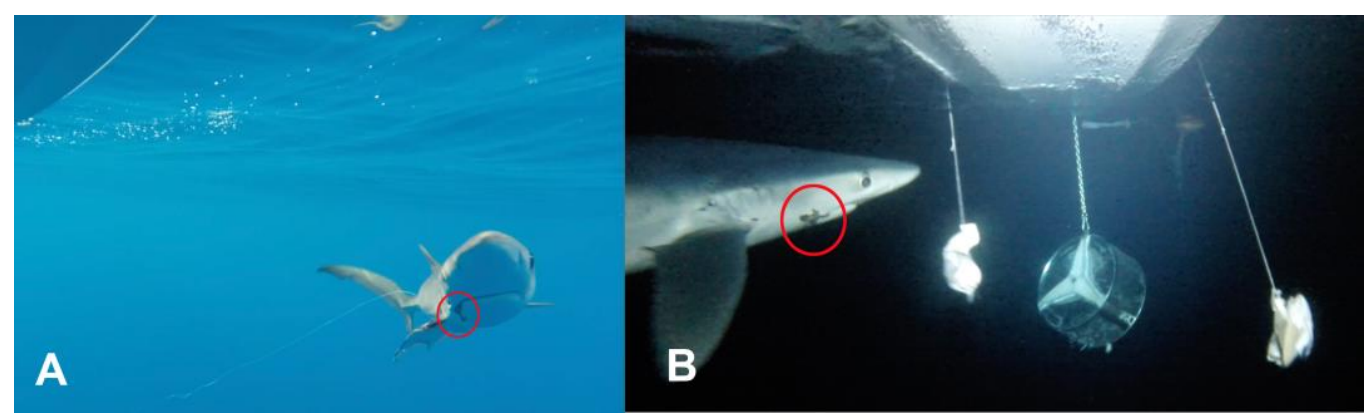

Figure 3. Photographs from video footage of two blue sharks (\#S3 and S\#2, respectively) that appeared (A) during the day and (B) at night in "Puerto Soller". Red circles indicate the presence of embedded hooks in the jaw.

In addition to sharks, the BRUVs allowed the observation of several other marine species, including teleost fishes such as Wreckfish (Polyprion americanus) (in July), Dolphin-fish (Coryphaena hippurus L.) (mainly in August), Pilotfish (Naucrates ductor) and Grey triggerfish (Balistes capriscus) (mainly in November/December), and squid (Loligo vulgaris) (at night during summer sessions). Schools of small size pelagic fishes were also frequent, for which the identification of the species was impossible to carry out without increasing the size of the images.

\section{Discussion}

The blue shark is among the most widely distributed sharks and is found in tropical and temperate areas of all oceans from about $60^{\circ} \mathrm{N}$ to $50^{\circ} \mathrm{S}$ [19]. The species is relatively fast-growing and fecund, reaching sexual maturity in 4-7 years and producing up to 135 pups per litter (average 37 pups) after a relatively short $(<12$ months) gestation period compared to other shark species [20,21]. Despite these characteristics, blue shark populations in the Mediterranean Sea have decreased by $>95 \%$ [15], probably due to overfishing [22], and the species is now classified by the International Union for Nature Conservation (IUCN) as "critically endangered" in this region [23]. This low abundance has made blue sharks very difficult to observe in the Mediterranean Sea. However, we were able to successfully observe multiple individuals in Balearic waters using our $24 \mathrm{~h}$ extended BRUV system. The system also allowed for the detection of residual fishing hooks inside or close to the mouth of several animals as a proxy for frequent and potentially deleterious interactions with fisheries. This result demonstrates the effectiveness of long-duration BRUVs for detecting shark species that occur at low densities, and contributes to an increased understanding of their biological status and the need to improve conservation. The fact that blue sharks were observed almost as often at night as during the day is not at all surprising, as this species has showed a clear diel behaviour, generally occupying shallower depths at night than during the day [24]. The occurrence of only seven blue shark individuals in 55 days ( $1335 \mathrm{~h}$ ) of BRUV sampling supports concerns that this species has been heavily overfished in the Mediterranean Sea, as previously occurred in the western English Channel by the 1970s [25]. We used the preferred prey of blue sharks (squid, [26]) as an attractant, hence it is unlikely that our methodology was unable to effectively attract the vast majority of animals reached by the olfactory stimulus. We also used cetacean flesh and oil to attract white sharks which opportunistically feed on the corpses of marine mammals [27], and fish baits which should attract a wide range of shark species. The rarity of blue shark sightings and the absence of other sharks in BRUV videos supports the conclusion that the abundances of large epipelagic sharks remain extremely low in the Mediterranean Sea [15].

Although our study was not able to provide quantitative information about elasmobranch species among the western Mediterranean in order to compare it with previous studies in the same area [28], our long-endurance BRUV was effective in detecting the presence of elusive species, such as the blue shark or the Wreckfish, whose presence in this part of the Mediterranean was usually inferred from 
stomach contents analysis [29]. Unsurprisingly, it also allowed for other more common pelagic teleost fishes and cephalopods to be detected. This device could be further modified to provide real-time observations by adding a wireless video transmitter (i.e., $1.3 \mathrm{GHz}$ ) to the system. This could be useful for notifying researchers of shark presence if physical samples (e.g., DNA biopsies) are needed. Such a system could also allow the development of a shark-watching industry for ecotourism purposes, such as that which exists in the Azores [30]. It could also be a useful tool for education and outreach purposes, where live videos could be streamed to a web page that also includes BRUV 'highlights'.

This long-endurance BRUV would improve the study of a broad spectrum of epi-pelagic marine species and would undeniably optimise the chances of observing animals in very low densities, including at night.

Author Contributions: Conceptualization, A.T., A.-M.A. and E.E.G.C.; methodology, E.E.G.C.; software, A.T. validation, A.T., A.-M.A. and E.E.G.C.; formal analysis, E.E.G.C.; investigation, A.T., A.-M.A. and E.E.G.C.; resources, A.T., A.-M.A. and E.E.G.C.; data curation, E.E.G.C.; writing-original draft preparation, E.E.G.C.; writing-review and editing, A.T. and A.-M.A.; visualization, A.T., A.-M.A..; supervision, E.E.G.C.; project administration, A.T. and E.E.G.C.; funding acquisition, A.T. and E.E.G.C. All authors have read and agreed to the published version of the manuscript.

Funding: The Shark-Med project benefits from the financial support of the Marilles Foundation (www.marilles.org).

Acknowledgments: The authors wish to thank Guillem Mateu Vicens (UIB) for his advice and support in developing this common project, Carl Meyer from the University of Hawaii, and Jeanine Almany from the CRIOBE (France) for some editing suggestions, as well as the Palma Aquarium for providing us with bait and the Conselleria Medi Ambient, Agricultura i Pesca of Mallorca (Spain) for providing us authorisation for our studies.

Conflicts of Interest: The authors declare no conflict of interest.

\section{Appendix A}

Average cost of components of the adapted board (does not include the cost of production and technical know-how)

\begin{tabular}{|c|c|}
\hline ITEM & Approx. Price in \$US \\
\hline 1. Surfboard: (potentially recycled)* & 300 \\
\hline 2. Anchor, rope and buoy & 30 \\
\hline 3. Washing machine drum: (potentially recycled)* & 100 \\
\hline 4. Gopro Hero 3+ & 190 \\
\hline 5. 256 Gb Mini SD memory card (needs 2) & 40 \\
\hline 6. Monitor and external power connector & 15 \\
\hline 7. Underwater video light & 60 \\
\hline 8. 12 V 60 Ah AGM Battery & 108 \\
\hline 9. Solar pannel & 24 \\
\hline 10. Gharge controller & 13 \\
\hline 11. Flag, white position light and radar reflector & 50 \\
\hline 12. Protection alluminum box & 90 \\
\hline 13. Easy access inox camera and light support & 90 \\
\hline 14. $22 \mathrm{~mm}$ plastic mast base & 6 \\
\hline 15. $20 \mathrm{~mm}$ alluminum mast & 12 \\
\hline 16. Inox chain and shackles & 40 \\
\hline TOTAL (with all components) & 1070 \\
\hline TOTAL* (including recycled components) & 670 \\
\hline
\end{tabular}




\section{References}

1. Ellis, D.; DeMartini, E. Evaluation of a video camera technique for indexing abundances of juvenile pink snapper, Pristipomoides filamentosus, and other Hawaiian insular shelf fishes. Fish. Bull. 1995, 93, 67-77.

2. Harvey, E.; Shortis, M. A system for stereo video measurement of sub-tidal organisms. Mar. Technol. Soc. J. $1995,29,10-22$.

3. Langlois, T.J.; Harvey, E.S.; Fitzpatrick, B.; Meeuwig, J.J.; Shedrawi, G.; Watson, D.L. Cost-efficient sampling of fish assemblages: Comparison of baited video stations and diver video transects. Aquat. Biol. 2010, 9, 155-168. [CrossRef]

4. Mallet, D.; Pelletier, D. Underwater video techniques for observing coastal marine biodiversity: A review of sixty years of publications (1952-2012). Fish. Res. 2014, 154, 44-62. [CrossRef]

5. Andradi-Brown, D.A.; Macaya-Solis, C.; Exton, D.A.; Gress, E.; Wright, G.; Rogers, A.D. Assessing Caribbean shallow and mesophotic reef fish communities using baited-remote underwater video (BRUV) and diver-operated video (DOV) survey techniques. PLoS ONE 2016, 11, e0168235. [CrossRef]

6. Kiggins, R.S.; Knott, N.A.; Davis, A.R. Miniature Baited remote underwater video (mini-BRUV) reveals the response of cryptic fishes to seagrass cover. Environ. Biol. Fishes 2018, 101, 1717-1722. [CrossRef]

7. Roberts, L.; Pérez-Domínguez, R.; Elliott, M. Use of Baited remote underwater video (BRUV) and motion analysis for studying the impacts of underwater noise upon free ranging fish and implications for marine energy management. Mar. Pollut. Bull. 2016, 112, 75-85. [CrossRef]

8. Ghazilou, A.; Shokri, M.R.; Gladstone, W. Animal v. plant-based bait: Does the bait type affect census of fish assemblages and trophic groups by Baited remote underwater video (BRUV) systems? J. Fish. Biol. 2016, 88, 1731-1745. [CrossRef]

9. Brena, P.F.; Mourier, J.; Planes, S.; Clua, E. Shark and ray provisioning: Functional insights into behavioral, ecological and physiological responses across multiple scales. Mar. Ecol. Prog. Ser. 2015, 538, $273-283$. [CrossRef]

10. FINPRINT Project (2019). Available online: https://globalfinprint.org/ (accessed on 2 January 2020).

11. Spaet, J.L.; Nanninga, G.B.; Berumen, M.L. Ongoing decline of shark populations in the Eastern Red Sea. Biol. Conserv. 2016, 201, 20-28. [CrossRef]

12. Speed, C.W.; Rees, M.J.; Cure, K.; Vaughan, B.; Meekan, M.G. Protection from illegal fishing and shark recovery restructures mesopredatory fish communities on a coral reef. Ecol. Evol. 2019, 9, 10553-10566. [CrossRef]

13. Heithaus, M.R.; Frid, A.; Wirsing, A.J.; Worm, B. Predicting ecological consequences of marine top predator declines. Trends Ecol. Evol. 2008, 23, 202-210. [CrossRef]

14. Ferretti, F.; Myers, R.A.; Serena, F.; Lotze, H.K. Patterns and ecosystem consequences of shark declines in the ocean. Ecol. Lett. 2010, 13, 1055-1071. [CrossRef]

15. Ferretti, F.; Myers, R.A.; Serena, F.; Lotze, H.K. Loss of large predatory sharks from the Mediterranean Sea. Conserv. Biol. 2008, 22, 952-964. [CrossRef]

16. Morey, G.; Martinez, M.; Massuti, E.; Moranta, J. The occurrence of white sharks, Carcharodon carcharias, around the Balearic Islands (western Mediterranean Sea). Environ. Biol. Fishes 2003, 68, 425-432. [CrossRef]

17. Morey, G.; Massti, E. Record of the copper shark, Carcharhinus brachyurus, from the Balearic Islands (Western Mediterranean). Cybium 2003, 27, 53-56.

18. Morey, G.; Soldo, A.; Riera, F.; Serena, F. Records of Carcharhinus limbatus and C. plumbeus (Chondrichthyes: Carcharhinidae) from off the Balearic Islands (NW Mediterranean). Cybium 2008, 32, 195-200.

19. Last, P.R.; Stevens, J.D. Sharks and Rays of Australia, 2nd ed.; CSIRO: Melbourne, Australia, 2009.

20. Gubanov, Y.P.; Grigor'yev, V.N. Observations on the distribution and biology of the Blue shark Prionace glauca (Carcharhinidae) of the Indian Ocean. J. Ichthyol. 1975, 15, 37-43.

21. Castro, J.A.; Mejuto, J. Reproductive parameters of Blue shark, Prionace glauca, and other sharks in the Gulf of Guinea. Mar. Freshw. Res. 1995, 46, 967-973. [CrossRef]

22. Biton-Porsmoguer, S.; LLoret, J. Potentially unsustainable fisheries of a critically-endangered pelagic shark species: The case of the Blue shark (Prionace glauca) in the Western Mediterranean Sea. Cybium 2018, 42, 299-302.

23. Dulvy, N.K.; Allen, D.L.; Ralph, G.M.; Walls, R.H.L. The Conservation Status of Sharks, Rays and Chimae $\neg$ ras in the Mediterranean Sea; IUCN: Málaga, Spain, 2016; 14p. 
24. Stevens, J.D.; Bradford, R.W.; West, G.J. Satellite tagging of Blue sharks (Prionace glauca) and other pelagic sharks off eastern Australia: Depth behaviour, temperature experience and movements. Mar. Biol. 2010, 157, 575-591. [CrossRef]

25. Vas, P. The abundance of the Blue shark, Prionace glauca, in the western English Channel. Environ. Biol. Fishes 1990, 29, 209-225. [CrossRef]

26. Clarke, M.R.; Stevens, J.D. Cephalopods, Blue sharks and migration. J. Mar. Biol. Assoc. UK 1974, 54, 949-957. [CrossRef]

27. Boldrocchi, G.; Kiszka, J.; Purkis, S.; Storai, T.; Zinzula, L.; Burkholder, D. Distribution, ecology, and status of the white shark, Carcharodon carcharias, in the Mediterranean Sea. Rev. Fish. Biol. Fish. 2017, 27, 515-534. [CrossRef]

28. Gouraguine, A.; Hidalgo, M.; Moranta, J.; Bailey, D.M.; Ordines, F.; Guijarro, B.; De Mesa, A. Elasmobranch spatial segregation in the western Mediterranean. Sci. Mar. 2011, 75, 653-664.

29. Deudero, S.; Morales-Nin, B. Occurrence of Polyprion americanus under floating objects in western Mediterranean oceanic waters, inference from stomach contents analysis. J. Mar. Biol. Assoc. UK 2000, 80, 751-752. [CrossRef]

30. Torres, P.; Bolhão, N.; Da Cunha, R.T.; Vieira, J.A.C.; Dos Santos Rodrigues, A. Dead or alive: The growing importance of shark diving in the Mid-Atlantic region. J. Nat. Conserv. 2017, 36, 20-28. [CrossRef]

(C) 2020 by the authors. Licensee MDPI, Basel, Switzerland. This article is an open access article distributed under the terms and conditions of the Creative Commons Attribution (CC BY) license (http://creativecommons.org/licenses/by/4.0/). 